\begin{tabular}{l|l} 
Variants & $\begin{array}{l}\text { Variants } \\
\text { The Journal of the European Society for Textual } \\
\text { Scholarship }\end{array}$
\end{tabular}

12-13 | 2016

Varia

\title{
Melodic Variance in the Songs of Thibaut de Champagne
}

Christopher Callahan and Daniel E. O'Sullivan

\section{OpenEdition \\ Journals}

Electronic version

URL: http://journals.openedition.org/variants/276

DOI: $10.4000 /$ variants. 276

ISSN: 1879-6095

\section{Publisher}

European Society for Textual Scholarship

\section{Printed version}

Date of publication: 31 December 2016

Number of pages: 11-33

ISSN: 1573-3084

\section{Electronic reference}

Christopher Callahan and Daniel E. O'Sullivan, « Melodic Variance in the Songs of Thibaut de

Champagne », Variants [Online], 12-13 | 2016, Online since 01 May 2017, connection on 01 May 2019 URL : http://journals.openedition.org/variants/276 ; DOI : 10.4000/variants.276 


\title{
Melodic Variance in the Songs of Thibaut de Champagne
}

\author{
Christopher Callahan and Daniel E. O'Sullivan
}

Abstract: Editing monophonic songs of Old French poets from roughly the second half of the twelfth to the early fourteenth centuries, poses several challenges, not least of which requires addressing variance on the level of both text and melody. Thibaut IV, king of Navarre, left his public over sixty songs characterized by generic breadth, registral subtlety, and varying melodic range. While providing reliable versions for study and performance, editors still need to help readers glimpse musical alternatives and variants in meaningful ways; otherwise, they run the risk of diminishing readers' understanding of the trouvère tradition. In this article, the authors examine micro-variation in concordant melodies as well as how information on non-concordant, unica melodies and rhythmic interpretations in later manuscripts fleshes out a musical aesthetic that appears, but is not, simple and straightforward. Keywords: Philology, Scholarly editing, Music editing, Mediaeval manuscripts, French literature.

Scholars of Old French have long resisted the overly positivistic editorial policies associated with the nineteenth-century classical philologist Karl Lachmann, who sought to reveal an original text from extant, imperfect copies, scrubbed clean of scribal errors and contamination. Philologists subsequently turned to Joseph Bédier's "best-text" approach as the most intellectually defensible policy: editors edit one witness for clarity and note all variants, regardless of their relative merit, in the apparatus. A few decades after Bédier's passing, textual variants worked their way back to respectability as Paul Zumthor elucidated the fundamental notion of mouvance in Mediaeval textuality $(1979,610)$. Mediaeval texts are based, paradoxically, on instability. ${ }^{1}$ Manuscript witnesses preserve mere traces of ephemeral experience of Mediaeval texts that were read or performed aloud, heard by a public, transformed by subsequent performers, written down by someone, copied then by someone

The rise of genetic criticism in the years after the wane of positivism has perhaps facilitated its focus on process and evolution and freed it from the methodological baggage that Mediaeval textual criticism continues to carry. 
else, etc. ${ }^{2}$ As texts were constantly reworked, either consciously or otherwise through the stages of transmission, no single entity was responsible for what survives to this day. Editors must come to terms with this situation if they wish to convey the real conditions of the pre-print, oral culture that produced these works.

Editing trouvère lyric, the monophonic songs of Old French poets from roughly the second half of the twelfth to the early fourteenth centuries, poses several challenges, not least of which requires addressing variance on the level of text and melody. Thibaut IV, count of Brie and Champagne and king of Navarre, left aficionados of Mediaeval song a particularly large (more than sixty songs) and rich corpus in terms of generic breadth, registral subtlety, and melodic range. The first complete edition of Thibaut's songs, published by Axel Wallensköld (1925), remains the standard reference work on Thibaut. ${ }^{3}$ Wallensköld takes an editorial position midway between Lachmann and Bédier, creating an ideal reading based on "[le] choix de la meilleure des variantes parmi celles que la filiation des manuscrits permet d'accepter" (1925, xcviii) ("the choice of the best variants that the manuscript filiations allow") rather than recovering an urtext. The latter task proved impossible owing to the "contaminated" state of the manuscripts because "ils remontent directement ou indirectement à plusieurs sources

2 “Le texte est la 'trace' de l'œuvre: trace orale, fuyante, déformable. L'érudition accumulée depuis un siècle a presque constamment méconnu le seul point digne d'intérêt: le fait même de cette dérivation langagière dont on observe les effets chez nos vieux poètes, inventeurs, au sein de langues nouveaunées, d'une 'écriture', qui pour cette même raison, ne pouvait rien devoir à des traditions antérieures, sinon de façon externe et anecdotique. 'Écriture' du reste convient mal puisqu'il s'est longtemps agi de chant seul" (Zumthor 1972, 95) ("The text is a 'trace" of the work, an oral, fugitive trace, which is easily deformed. The last century of accumulated erudition has almost invariably misunderstood the only point of real interest: the very fact of the text's basis in spoken language. This linguistic source, whose effects are observable in the works of our earliest poets, who invented a 'written language' in the midst of the emerging vernaculars, cannot for that very reason owe anything to earlier traditions, except in an anecdotal way exterior to the texts themselves. 'Written language' is, in any case, an inappropriate term, since song unsupported by a text for reading was for long the only mode of existence for these works.")

3 The earliest melodic edition devoted to Thibaut, H. Anglès's Canciones del rey Teobaldo (1973), was compiled posthumously from the author's notebooks and is at best a work in progress. 
utilisées en même temps" (1925, xcviii) ("they derive directly or indirectly from several sources used simultaneously"). His published version may thus be found directly in one manuscript or combined from more than one source under the cover of a uniform orthography (usually taken from trouvère MS K-Paris, Arsenal 5196), or it might be a hypothetical emendation when all manuscript readings are deemed to be faulty. Despite the obvious methodological faults in Wallensköld's edition, no one has yet produced an updated textual edition of Thibaut's songs. Perhaps more surprising, no one has edited Thibaut's melodic corpus until now. ${ }^{4}$

Editors of trouvère lyric have recently made strides in bridging what was once a yawning chasm between the concerns of philologists and musicologists, yet equal attention paid to variance in both text and melody remains elusive. The present study lays out theoretical and practical considerations to redress that concern in editing trouvère song in general and Thibaut's lyric in particular. After a brief history of editing trouvère music, we examine various sources of Thibaut's melodies to confront the question of melodic variance. If recognizing the unstable foundation of Mediaeval textuality proves essential for understanding, say, Chrétien de Troyes or Froissart, confronting variance in trouvère melody, or so we contend, is equally crucial for appreciating the trouvère art. Such a confrontation must first address the largest collection of melodies that derive from chansonniers and that preserves melodies that vary only in minor ways among themselves. However, minor variance can pose major problems. Moving out from that central question, we look at two sources that offer entirely different melodies that sometimes utilize contemporary melodic structures and sometimes adopt seemingly older, even anachronistic conceptions of monody. Two other chanter sources preserve melodies that try to conform to new musical conceptions based on polyphonic forms. Finally, we explore the liminal cases of melodic variance - contrafacture

4 With Marie-Geneviève Grossel, the authors are completing an edition of Thibaut's texts and melodies to appear with Champion publishers in Paris. Although Hans Tischler includes Thibaut's songs in his 1997 compendium of trouvère lyrics with melodies, the authors feel that his editorial enterprise was too broad to consider it equal to a bona fide edition of the king's œuvre, for hints to Thibaut's unique take on the trouvère art are utterly undetectable in Tischler's massive opus. See below for further comments on Tischler's editorial approach. 
and palimpsests - and examine the boundaries of the editorial enterprise.

\section{Current state of trouvère editing}

Early twentieth-century editions, steeped in Lachmannian textual ethics, not only obscured the inherent vagaries of manuscript transmission but also generally stripped the poetic text of its melody, altering its identity as an artifact rooted in performance. A notable exception to this practice was Joseph Bédier's 1912 edition of the trouvère Colin Muset, which offered eight melodies but relegated them to the back of the volume. Regrettably, Bédier's subsequent edition of Colin Muset (1938) contained no music, a norm which prevailed for the next four decades. ${ }^{5}$ Poetry being more accessible to musicologists than Gregorian notation to philologists, a scholar such as Friedrich Gennrich $(1951,1963)$, in his extensive publications on Mediaeval lyric, integrated music and poetry in ways that textual scholars did not feel qualified to do. But these were performance editions whose scholarly apparatus focused on the music, and they did not offer critical discussion of the texts. ${ }^{6}$

In the late 1970s philologists and musicologists, who had hitherto worked in isolation, each asking their own, discipline-specific questions of the manuscripts, began to collaborate. Samuel N. Rosenberg and Hans Tischler's Chanter m'estuet (1981) proved to be a milestone in trouvère scholarship, closely followed by The Lyrics and Melodies of Gace Brulé (1985), in which Rosenberg collaborated with Samuel Danon (co-translator) and Hendrik van der Werf, and a re-edition of Chanter m'estuet in 1995. The latter two publications boast modern translations in either French (Chanter m'estuet) or English (Gace Brulé), which is also the case for Rosenberg's next collaborative project, Songs of the Troubadours and Trouveres (1997), with musicologists Margaret Switten and Gérard Le Vot.

5 J.-B. Beck, the musicologist responsible for the melodic transcriptions in 1912, was living in the United States while the other obvious candidate, Pierre Aubry, had died in a fencing accident (Haines 1997), hence the dearth of skilled collaborators on the musical side of things.

6 Indeed, this situation continues to characterize even more recent compendia by musicologists working solo (Van der Werf 1977-79, 1984; Tischler 1997). 
The readability and concision of this last edition's layout succeeds admirably in being at once a scholarly and a performance edition. Because these first collaborative efforts constituted a great leap forward from previous editions, only in retrospect are their shortcomings with regard to variance, in particular their attention only to textual and not to melodic variants, becoming apparent.

The earliest edition to address melodic variance is also the most accessible to the neophyte:Hendrik van derWerf's Trouvère-Melodien (1977), an edition that put into practice much of what van der Werf outlined in his seminal work, The Chansons of the Troubadours and Trouvères (1972). It lays out all melodies synoptically, line by line, for each song. ${ }^{7}$ The completeness of van der Werf's layout creates a curious shortcoming: its page-by-page presentation of each poetic line hinders the reader's ability to grasp both the overall shape of the melodic contour and the role of repeated micro-gestures in constructing it (see O'Sullivan 2008, 66-67). Furthermore, readers lose sight of the distinction between major and minor variants, and variant melodies are not treated differently from those which are altogether different. ${ }^{8}$

These shortcomings were admirably addressed by Avner Bahat and Gérard Le Vot in an edition of Blondel de Nesle's melodies (1996) that presents melodies synoptically but groups manuscripts by stemmata, thus facilitating the focus on variation. They employ a notational system in which below the base melody only variants are recorded as note heads, while completely concordant lines are differentiated with a system of forward and backward slashes, according to whether they occur within or across manuscripts (or both). Melodic isolates, finally, are presented separately from these concordant and semi-concordant layouts, avoiding the kind of visual overload that the reader of Trouvères-Melodien can fall prey to. Published to years after Yvan LePage's textual edition of Blondel (1994), moreover, it is unclear whether LePage's and Bahat/ Le Vot's editions were conceived as companiona volumes. Though

\footnotetext{
7 Because van der Werf's edition only records love songs, for a poet like Thibaut nearly half of his poetic corpus - his debate songs, political and devotional songs, and pastourelles are regrettably omitted - is absent.

8 These "marginal" melodies have traditionally been roundly disparaged by musicologists (Karp 1964; Bahat and Le Vot 1996), but their value has recently been reassessed (Callahan 2013).
} 
the melodies are set over the first stanza of LePage's edited texts, the text editor does not reference the melodic study in any way. Rather, the latter appears to have been designed after the fact in order to redress the imbalance inherent in yet another lyric edition without music, and as such was free to set its own course. Regrettably, it is the Mélodies volume's very innovativeness and erudition which limit its accessibility to scholarly audiences without training in Mediaeval music, thus offsetting its benefits to a certain degree.

Lastly, Hans Tischler's monumental Trouvère Lyrics with Melodies: Complete Comparative Edition (1997) presents serious issues of legibility. For it imposes a different rhythm on every single melody, though rhythm is systematically notated in only one late thirteenth-century trouvère chansonnier, Paris, BnF, fr. $846 .{ }^{9}$ As a result, the mostly identical melodic contours shared by numerous manuscripts are deftly obscured in a plethora of perceived subdivisions. ${ }^{10}$ The distinction between base melody and variants is thus difficult to determine, as every melody appears to be radically different from every other. Furthermore, although this opus is not organized artificially by genre, as was the case with single-author anthologies of the twentieth century, neither is it organized by poet, thereby enabling researchers to locate intact the corpus of individual trouvères. Rather, the entire body of trouvère song is organized alphabetically by incipit, as was Raynaud's Bibliographie of 1884, rendering the study of individual poets more than arduous.

While the above survey is necessarily abbreviated and selective, it illustrates the earnest attempts of editors to convey trouvère song. Furthermore, because lacunæ have been progressively filled over time - editions with no music were replaced by collections with some music, which, in turn, gave way to anthologies that begin to address melodic variance - it is only logical to suspect that other

9 Paris, BnF, fr. 12615 (MS T) contains a section of motets notated in modal rhythm, unlike those in Paris, BnF, fr. 844 (MS M). Mensurated melodies in a fourteenth-century hand were added, however, to the empty staves of a number of M's monophonic songs between ff. 169 and 211. This same hand appears responsible for the instrumental dance tunes found on $\mathrm{ff} .5 \mathrm{r}$ and 103r-104v.

10 These manuscripts include Paris, Arsenal 5198 (MS K); Paris, BnF, fr. 845 (MS N); Paris, BnF, fr. 847 (MS P); and Paris, BnF, n.a.f. 1050 (MS X). Similarly, Paris, BnF, fr. 844 (MS M) and Paris, BnF, fr. 12615 (MS T) also share similar melodic contours. 
holes remain to be filled. As a means of conveying more concretely what these holes could consist of, we now address specific problems presented by the editing of Thibaut's songs.

\section{Small-scale variance among the major sources}

The majority of musical sources that preserve Thibaut de Champagne's melodies are formatted into large songbooks. Organization of chansonniers by genre, something that has been a common practice in modern editions, came into its own in Artois and in the decades after 1270, whereas lyric anthologies compiled in the two decades following Thibaut's death (1253) juxtaposed, instead, a variety of song types, accentuating the permeability of intergeneric boundaries in trouvère song (Callahan 2012a). Significantly, in Thibaut's case, his religious lai was placed near the center of MS Mt, the libellus devoted to his corpus which was inserted into Paris, BnF, fr. 844 (MS M) soon after the latter's composition (Baumgartner 1987; Barbieri 1999; Haines 2002). As Wallensköld's synoptic table at the end of his edition makes clear, this principle of chansonnier organization extended to most other early manuscripts, and by reproducing this order, an editor can offer the modern scholar / performer something of the Mediaeval experience of reading as intended by those responsible for these early collections, who may or may not have well included Thibaut's works (Huot 1987; Formisano 1993; Haines 2004).

In editing the melodies of the grands chansonniers, the thorniest question may be micro- or minor variation, i.e. variation in segments shorter than one line. It is difficult because we believe that trouvères employed ornaments and cultivated performative styles that went beyond a melodic skeleton (see Table 1 for examples of both large- and small-scale variation). Most of Thibaut's melodies, and this goes for most trouvères of his generation, used a bipartite structure that makes some of the work easier, because certain repetitions are predictable. In this structure, the stanzaic melody is divided between frons (or head) and cauda (or tail). It is the frons that proves the most regular in structure, and critics often schematize it as $\mathrm{ABAB}$, where a melody $\mathrm{A}$ accompanies the first and third line of verse and melody $B$ is set to the second and fourth. This symmetrical structure can help determine what musical gestures 
were part of the base melody and what might have been ornamental flourishes on the part of the performer from whom the scribe heard the melody or perhaps even on the part of the scribe himself. So if we see, for example, a two-note neume at the end of the second line and a three-note neume at the end of the fourth, as long as the final, structural tone is the same, it is safe to consider this variant as analagous to minor textual, perhaps orthographical, variants that need not encumber the apparatus.

Editing the frons of melodies is not always so straightforward. For example, if we take the melody accompanying RS 324 from just three of nine extant sources - Paris, Arsenal 5198 (MS K); Paris, BnF fr. 844 (MS Mt); and Paris, BnF fr. 846 (MS O) - significant melodic variance appears (Table 1$).{ }^{11}$

The melody in MS K begins on A, rises in conjunct (step-wise) fashion to $\mathrm{D}^{\prime}$, where it briefly recites, establishing $\mathrm{D}$ as a modal pole, and descends conjunctly to cadence on G. The next phrase takes this cadential pitch as its point of departure, again inscribing a rising-falling curve of a fourth before returning to the starting pitch, reinforcing the suggestion of transposed Dorian mode. The melody of MS Mt shows a similar rising-falling contour, but with a different starting pitch $(G)$, and cadences via disjunct movement a third above its starting pitch. Unlike $K$, which cadences on the sub final, an unstable pitch which vigorously relaunches the second phrase, Mt's cadential pitch invites suspension. The two melodies inscribe in effect, in the second phrase, a melodic curve of identical range, rising to $C^{\prime}$ before falling, rising, and falling again to cadence on A. But as similarly as these melodies behave in the frons, their modal structure is quite different, and the cauda reveals them to be unrelated.

Examination of other manuscripts shows $\mathrm{K}$ to be the outlier, and $\mathrm{Mt}$ to be concordant with the other seven chansonniers that notate this song (three more do not record the music). Turning to the example of MS O, we see small-scale variation visible in the

11 Readers can consult high-quality images of the manuscripts in question on www.gallica.fr. Specifically, images of RS 324 can be found at http:// gallica.bnf.fr/ark:/12148/btv1b550063912/f78.item (MS K, p. 52), http://gallica. bnf.fr/ark:/12148/btv1b550063912/f79.item (MS K, p. 53), http://gallica.bnf.fr/ ark:/12148/btv1b84192440/f155.item (MS Mt, f. 69r), and http://gallica.bnf.fr/ ark:/12148/btv1b6000950p/f136.item (MS O, f. 53v). 
concordant melodies of manuscripts $\mathrm{Mt}$ and $\mathrm{O}$. The differences between the two lie primarily in ornamentation: whether a given syllable is notated with one pitch or several. In phrases 1 and 3 of the frons, syllables 3 and 8 and ornamented now in $\mathrm{O}$ now in Mt, while in phrases 2 and 4, the last word is ornamented equally but differently in each. Again, while phrases 5 and 7 are identical, phrases 6 and 8 are ornamented differently, with each melody taking the lead in turn. The comparison to $\mathrm{O}$ also helps highlight places where Mt shows inconsistencies in the melodies of its pedes, which in theory are identical: phrases 1 and 3 cadence on different pitches while the eighth syllable in phrase 1 is ornamented and the same syllable in phrase 3 is not. Similarly, the step-wise curve of phrase 2 is leveled in phrase 4 to two series of identical pitches. Comparison of $\mathrm{Mt}$ with $\mathrm{K}$ thus reveals large-scale differences of the kind that require special treatment in the critical apparatus, and minor variation between $\mathrm{Mt}$ and $\mathrm{O}$ requires an even lighter hand.

No classic or standard structure as for the trouvère frons exists for the cauda, an absence that complicates the verifying of a melo$\mathrm{dy}^{\prime} \mathrm{s}$ internal structure. While repetitions occur in this part of the stanza at a level smaller than the entire phrase, they are often subtle. For example, in the cauda of $\mathrm{K}$, the ends of phrases 5 and 7 are repeated exactly, which helps break the cauda into two parts, endowing it with some internal structure. Such is not the case in Mt and O. In those caudae, the melody over syllables 4-8 in phrase 5 is repeated over the same passage in phrase 7 , but it is pitched a third higher, thereby redistributing the sequencing of whole and half tones. ${ }^{12}$ When the melodies of the caudae of $\mathrm{Mt}$ and $\mathrm{O}$ are compared, we see, as we did in the frons, mostly variants in ornamentation. Nevertheless, the melodies in phrases 6 and 8 differ sufficiently between the sources to prompt an editor to ask if something more fundamental is going on here. For while the similarities in the frons might allow one to treat one manuscript's melody as a variant of the other's, the cauda does not, and the outlier should be presented so as to reveal these differences. In this case, there are enough similarities that $\mathrm{K}$ can be presented in a synoptic table, which will show its divergent cauda clearly. Furthermore, while

12 This transposition explains why the scribe of MS O (who is the most consistent in noting accidentals) did not place a B flat in phrase 5, which the ear otherwise expects. 


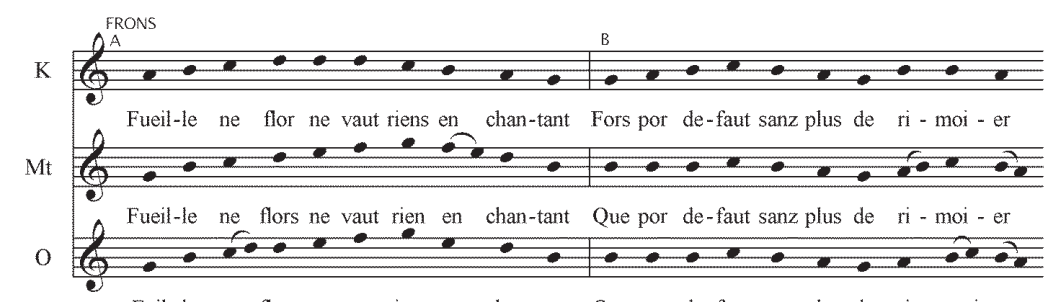

Fuil-le ne flors ne vaut riens en chan-tant Que por de-faut sanz plus de ri-moi-er

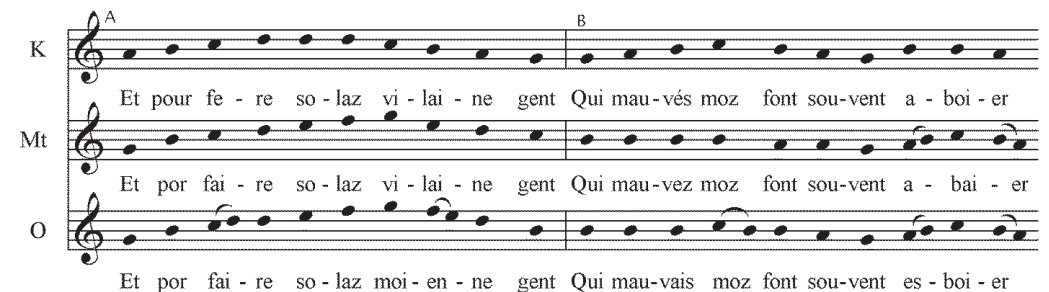

Et por fai - re so-laz moi-en - ne gent Qui mau-vais moz font sou-vent es - boi - er
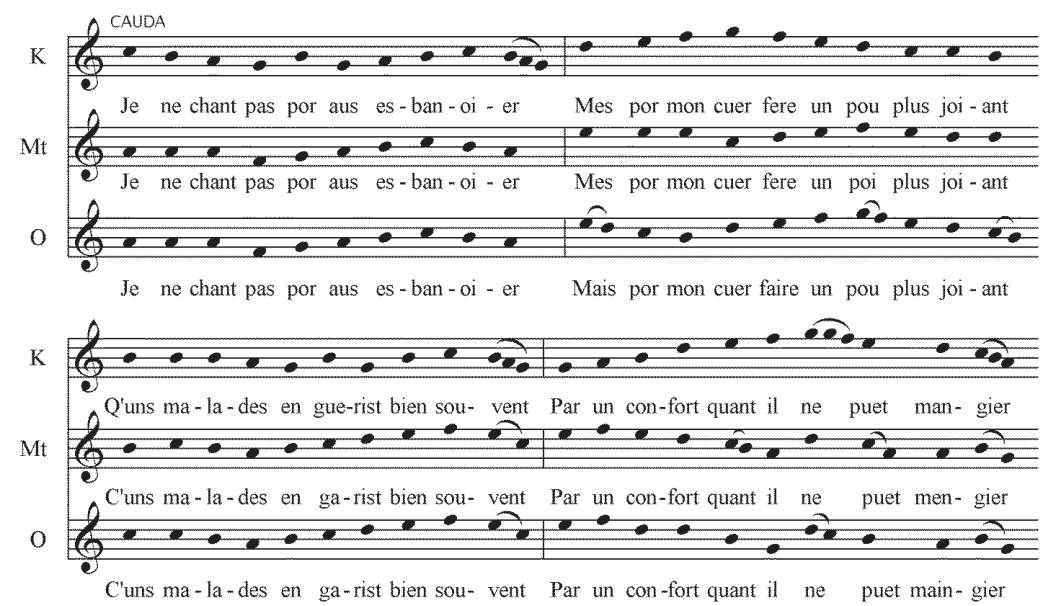

Table 1. Synoptic Transcription of stanza 1 of RS 324, MSS K, Mt, O.

more localized differences must also be noted, distinguishing ornamentation from more fundamental changes remains problematic.

How does one choose a base melody under such circumstances? This type of variation has been insightfully characterized as a snapshot of performance practice (van der Werf 1972, 29-34), and deserves to be fully notated in tables of variants, along with differences in pitch. ${ }^{13}$ There are nonetheless enough discrepan-

13 Where melodies are fully concordant, these passages can be left blank 
cies even among concordant melodies that music editors are left with the same questions - concerning scribal intention, scribal inattention, and scribal attention to modal coherence - that have troubled philologists since the eighteenth century. What constitutes a melodic variant? This question has rarely received an answer within the context of a critical edition, as variations in the music can alter the sense of the melodic line music in different ways than graphic and lexical variants change the sense of the poetic text. But just as text editors cannot record every graphic difference, music editors need to develop criteria that allow them to ignore insignificant differences in melody, though these may be more difficult to identify. While it is important, for the purposes of critical discussion, to distinguish between differences in ornamentation, which do not alter the mode, and differences in starting or cadential pitches or in interval content, which certainly can, it is our experience that small-scale variation in ornamentation constitutes valuable information about the performance practice of trouvère lyric. Thus, we favor a notational system that records variants to a maximum degree, highlighting these in such a way that the performer can easily construct alternate versions of the melody. At the same time, we will articulate a hierarchy of significance among variant types, which will be integrated into the critical discussion of the music. With as vast a corpus as editors face with a poet like Thibaut, the number and variety of whose sources perforce complicate the data, it is our goal to offer as complete a picture as possible of the reception of his œuvre across time and space. ${ }^{14}$

\section{Unica in MSS R and V}

Melodic unica are a relatively rare occurrence in Thibaut's corpus. Four chansonniers contain a single non-concordant melody - MSS Paris, Arsenal, 5198 (K), Paris, BnF, fr. 847 (P), Arras, BM, 657 (A), Berne, BM, 231 (B) - and two more - Paris, BnF, fr. 846 (O) et

in synoptic tables, so as not to detract from variants by cluttering lines with identical pitches.

14 Recent recordings (Diabolus in Musica 2005; Alla Francesca 2012) feature a single manuscript, a practice that supports our preference for choosing, for the chansonnier portion of the edition, texts and melodies from a single source. 
MS Rome, Vat., Reg. 1691 (a) - feature two. The majority of melodies transmitted with Thibaut's poems are thus concordant across manuscripts. Two chansonniers, however, Paris, BnF, fr. 1591 (R), and Paris, BnF, fr. 24406 (V), are notable for the significant number of melodies which are not associated with any other poem in the trouvère repertoire. Thirty percent (18 out of 60 ) of the Thibaut songs in MS V, and thirty-four percent (12 out of 35) of the Thibaut songs in MS R are notated with unique melodies; it is MS V's unica in particular which are held in disregard by the musicological community. Two features of these melodies underscore the vagaries of their transmission and make their place in editions of the trouvères highly relevant. ${ }^{15}$ First of all, the question of concordance appears to be aligned with that of genre: love songs are twice as likely to have concordant melodies, and thus to be part of a shared network of transmission, than jeux-partis and devotional songs. When isolating the debate genre, the percentage of unique melodies rises to over ninety percent. As contrafacture, i.e. borrowing of melodies and metrics, is prescribed for jeux-partis in Mediaeval poetic treatises such as the late thirteenth century Doctrina de Compondre Dictatz (Marshall 1972), the source of these borrowed-yet-unique melodies becomes of paramount importance, and leads us to the second consideration. The dominant structure of both concordant and unique melodies is $\mathrm{ABABx}$, as seen above: frons / cauda with the cauda (x) through-composed, i.e, without phrase-level repetition. A significant minority of unica, however, are entirely throughcomposed, or in oda continua, to use Dante's terminology from his De vulgari eloquentia. In the case of non-love songs, the percentage of melodies in oda continua increases dramatically, reaching ninety percent for debate songs. The significance of these statistics lies in the fact that the oda continua was a structure that dominated lyric composition in the twelfth century, while the thirteenth century saw an increasing preference for the frons / cauda structure, such that troubadour melodies recorded in oda continua in the earliest chansonniers were rewritten in the frons / cauda pattern a century later, thus reflecting current compositional fashion (Aubrey 1996, 49-65). From what models then are these jeux-parti melodies borrowed?

15 See Callahan 2013 for a detailed argumentation. 
The possibility that the sources are troubadour songs whose melodies have not otherwise come down to us is supremely tantalizing, as it explains at one and the same time their outmoded structure and their flawed transmission.

But of more immediate concern is how we are to integrate these melodies into an edition that seeks to recognize variance. While variants of concordant melodies will be noted in the critical apparatus, unica will be granted a place in the body of the edition. They will be notated either directly underneath the base melody or immediately after the presentation of the edited songs, as they represent distinct, legitimate performance options. Issues of structural coherence will be raised as needed in the Remarques section of each song, as these melodies are decidedly not so systematically "lacking in the most elemental logic" (Karp 1964, 27) as to deserve the trash bin of editorial practice. Rather, our presentation will serve to highlight all filiations and all possible performative practices with regard to Thibaut's songs.

\section{Rhythmic interpretations}

Owing to the existence of mensurated chansonniers such as MS $\mathrm{O}$, and particularly in light of the contentious history of modal theory as it has affected scholarship on troubadour and trouvère monody, the question of modal rhythm in an edition committed to celebrating manuscript variants cannot be ignored. How are we to treat the nearly systematic rhythmic notation of a chansonnier like O, or of T (Paris, BnF, fr. 12416), whose reading of Thibaut's "Por conforter mon corage" (RS 237) is measured while O's is not? Do the measured melodies of MS O reflect a rhythm, analogous to that used by polyphonic motets, that was present in trouvère song from the beginning but which most musical scribes were not trained to record? Or is the non-rhythmic notation of the majority of chansonniers truly reflective of the kind of imprecisely measured, text-based style that is used in Gregorian chant performance? An enlightened answer was brought to the question nearly a century ago by Jean Beck, one of the founders of modal theory, in his 1927 edition of MS O. While the technical aspects of Beck's methodology need not concern us here - he effectively forged a compromise between the German text-based and the French mensural 
approaches (Haines 2004, 216) - he significantly did not consider the proportional notation of MS O to reflect the original rhythm of the songs, but rather to be the interpretation of the copyist, working several generations after the fact (Beck 1927). His perspective on textual and melodic variance in fact adroitly supports the argument we are making here. ${ }^{16}$

An edition based on the sources as they survived around the time of Thibaut's death, such as MS Mt, for its selections, textual readings, and ordering of context, would seek to interpret musical notation as consistent with contemporary practice. Beck advocated, and reasonably so, interpreting the measured rhythms of MS O as a rewriting after the fact, a paraphrase so to speak by a scribe contemporary with Adam de la Halle and practiced in the notating of polyphony. By extension, the music scribes of Mt and other chansonniers prior to 1270 did indeed reflect, with their notation, the preferred performance practice of their time for monophony, both sacred and secular. A chronological and thus historically informed argument for unmeasured neumes is at the same time an argument for unmeasured transcriptions, the method sanctioned by musicologists over the last forty years, for it recognizes real difficulties with the solutions to rhythmic interpretation of this notation, which have frustrated musicologists since Friedrich Ludwig. As Beck acknowledges $(1927,64)$, while in most cases a single rhythmic mode (usually mode 1 - iambic) can be maintained throughout, this often results in mismatches, by the song's end, between tonic accents in the poetic line and beats in the music. In other cases, duration and accent can vary from one pes to the next, although the melody in both pedes is supposed to be identical (see above). It is particularly because musicologists in the first third of the twentieth century could not agree on a consistent method for teasing out the latent rhythm of troubadour and trouvère monody that, as early as 1934, Carl Appel proposed the unmeasured system of transcription that is nearly universally accepted today.

16 "Force nous est [...] de prendre [...] les chansons des divers chansonniers, telles que nous les trouvons, et de les traiter comme autant d'interprétations ou de réalisations des originaux à jamais perdus" (Beck 1927, 10) ("It is incumbent upon us to take the songs from various songbooks such as we find them, and treat them as so many interpretations or performances of originals that are forever lost to us"). 
If in a critical edition of the trouvères MS O should be chosen as the base manuscript for the melody of a given song, the most widely accepted approach today is to transcribe O's melodies in unmeasured notation but with the neumes accurately reproduced just above (Callahan and Rosenberg 2005, 120, 183-84, 190, 194). This solution has much to recommend it, as it offers an accurate representation of the manuscript page without committing the editors to a transcription that perforce highlights the type of rhythmic inconsistencies mentioned above. In the case of the motets of MS T, there is no question that they should be transcribed accurately, reproducing the rhythm that permits accurate part singing even in its infancy.

\section{Contrafacta and palimpsests}

A comprehensive view of melodic variance in trouvère song must include minor variation, unica, and rhythmic interpretations but move beyond the confines of songs attributed to a particular trouvère to consider the wider tradition. Melodies often moved independently from the texts to which they were originally set. A redeeming feature of Tischler's Trouvère Melodies (1997), despite the drawbacks detailed above and elsewhere, is that it constitutes an edition of melodies and their accompanying texts, not vice versa. However, Tischler's focus is on melodies whose stanzaic settings vary little from one source to another. Parts of trouvère songs travelled throughout the wider world of Mediaeval music, and these vagaries will prompt editors to ponder the limits of melodic variance. For example, if a song's melody is taken from other source, i.e. contrafacture, should an editor consider the original context as well as where it is reset to a trouvère's new text? What of partial or even whole palimpsests, places where melodies and texts were scratched out and completely or, even more importantly, partially replaced with other songs? ${ }^{17}$

17 Because they are tangential in Thibaut's corpus, refrains and motets are not treated here, but they may have important repercussions when editing other trouvère songs. Musicologist Ardis Butterfield points out the need to address both melody and text of refrains in her study of one particular refrain, "Hareu, li maus d'amer m'ochist!" (number 784 in Nico van den Boogaard's index) where melody remains the same as the accompanying text differs 
Mediaeval composers of all stripes, not just trouvères, practiced contrafacture. In Old French lyric, poets seemed more inclined to set new words to existing melodies in certain genres, especially religious lyric and debate songs, but examples in other contexts are not absent. ${ }^{18}$ Until now, trouvère scholars have been more than willing to include texts in varying contexts in editions. Should editors extend this logic to trouvère melodies when the latter survive in other contexts, i.e. when they are set to other texts? For example, Thibaut's debate with Baudouin, "Rois Thiebaut, sire, en chantant responnez" (RS 943), shares its melody with a love song attributed to the Chastelain de Couci: "Merci clamans de mon fol errement" (RS 671=1823). Of the fourteen surviving witnesses of the Chastelain's song, twelve preserve music. Thibaut may have selected the Chastelain's melody because of its popularity and because it would have prompted connections in the mind of knowing audience members, thus adding to the message and furthering the discursive aims of the jeu-parti. ${ }^{19}$ When editing Thibaut's music, should editors consult the melodies accompanying the Chastelain's songs? After all, even if we are certain that the Chastelain belonged to the generation of trouvères before Thibaut, both of their songs survive in the same sources, transcribed by the same scribes.

Contrafacture can move readers beyond typical trouvère-song contexts, i.e. the chansonniers. Adam de la Bassée composed the Ludus Super Anticlaudianum in the late thirteenth century. It is a reworking of Adam de Lille's Anticlaudianum of the late twelfth century, and throughout his work, Adam de la Bassée interpolates songs. ${ }^{20}$ These songs often take their melodies from Latin hymns

markedly (Butterfield 1991, 17). Moreover, because refrains often made their way into motets, the upper-voices of Mediaeval motets, despite the texts that accompany them, must be examined anew in discussions of melodic variance in the wider trouvère tradition. On refrains and motets, see especially Everist 1994.

18 Fundamental studies of contrafacta are Gennrich 1965 and Marshall 1980. For studies concerned primarily with Old French religious lyrics, see Drzewicka 1985, Calin 1986, Duys 1997, O'Sullivan 2005 (especially chapter one on Gautier de Coinci), and Callahan 2012b.

19 O'Sullivan studies melody and memory extensively in Thibaut de Champagne's jeux-partis and débats in a forthcoming article, "Contrafacture, Lyrical Exchange, and Parody in Thibaut de Champagne's Debate Songs".

20 The standard edition is Bayart (1930), and a thorough study of the work 
and sequences, but also from trouvère songs. One composition, Ave Gemma, a song in praise of Saint Agnes, uses the melody of Thibaut's "Tant ai Amors servies longuement" (RS 711), and we know that Adam was aware of the melody's source because he carefully noted the sources of his melodies in his text. Thibaut's song survives in many sources, a testament to its popularity, which is undoubtedly why Adam de la Bassée chose it: by building upon collective memory of the song, Adam was better able to get across his religious message. ${ }^{21}$ Because we know that Adam was using Thibaut and not vice versa, as Adam was clearly composing well after Thibaut's death, and in a monastery, editors might feel themselves absolved from having to consult Adam's version when editing RS 711. But then again, there are witnesses to Thibaut's songs that both predate and postdate the unica manuscript of the Ludus super Anticlaudianum that was produced in the north of France where many trouvère sources were compiled. It is therefore not beyond the pale to imagine that Adam's work might have been known by those who worked on shaping the trouvère legacy.

A more material kind of recontextualization of trouvère songs occurs through palimpsests - texts that have been scratched out and replaced by new texts. Sometimes the process was total, and the original texts are entirely obscured and recoverable only with the help of aids like ultraviolet light or multispectral imaging. However, some palimpsests were partial: a scribe would erase what he could not use, and keep the rest, filling in around it. This is the case for one source transmitting three of Thibaut's songs: British Library, Egerton 274. The manuscript has attracted mostly the attention of scholars interested in Philip the Chancellor's works, as the first part of the manuscript is dedicated to his songs, mostly monophonic but also a few polyphonic (see Whitcomb 2000). The witness preserves three of Thibaut's songs: RS 360, 711, and 2075. The first two are part of the chansonnier section of the manuscript, which Whitcomb, following Gennrich and Ludwig, have called Fascicle IV, though one could describe the codex's construction otherwise (O'Sullivan 2013a, 2-4). The third, Thibaut's famous

comes in J. Barnard's $2008 \mathrm{PhD}$ dissertation, supplementing the important article by Hughes (1970).

${ }_{21}$ The most recent discussion of this contrafacture comes in O'Sullivan (2013b). 
unicorn song, is found appended to Fascicle V, a series of Latin poems. Attributions to poets were not entered when the manuscript was composed but added later.

The melodies of these songs have not always survived and, more often than not, were altered significantly, which makes their place within the melodic repertory somewhat enigmatic. Whereas the above examples of variance in Thibaut's melodies have involved minor motivic variants or experimentation with mensural interpretation of otherwise concordant trouvère melodies, the melodies and much of the texts of the trouvères songs have become the fodder for palimpsests. A musical scribe has scratched away some neumes, added others, and kept still others intact. The works for initial stanzas, too, has been often scratched away and written over with Latin words that were meant to accompany the newly altered melodies. For example, "Tant ai amors servies longument" (RS 711), the song Adam used for Ave Gemma (see above), is preserved beginning on $\mathrm{f}$. $104 \mathrm{v}$ of Egerton 274 in a highly altered state. The words of the first stanza are scratched out and replaced with a Latin text praising Christ, also found in the Salisbury breviary for the feast of St. Michael..$^{22}$ Many musical notes are also scratched out and replaced - the ink of the interpolated music is clearly darker - sometimes with elaborate melismatic formulæ, as in the case of the second syllable of the phrase opening the third verse: "Te decet laus" ("You are worthy of praise"). ${ }^{23}$ In the other sources, this is a matter of a single note, but the musical interpolator of MS F inscribes a twelve-note melisma above that single syllable ("de"). A significant break in texture results, but in other lines, just as many original notes were left on the staves, and the Old French text from stanza two onwards also survives, potentially performable to the newly adapted music. ${ }^{24}$ The question that must be asked is whether or not these melodies have been altered to the point of being no longer recognizable as Thibaut's music. Or does the listener still hear phantom traces, echoes of the trouvère king's melodies?

22 The Latin text and basic bibliography on where to find this text can be found in Wallensköld (1925), 26 n1.

23 Egerton 274 may be viewed online at http://www.bl.uk/manuscripts/ FullDisplay.aspx?ref=Egerton_MS_274.

24 The preservation of decorated initials may have prompted the choice of a song for a particular palimpsest. 


\section{Conclusion}

Approaches to editing trouvère song that make both textual and melodic variance apparent have come a long way in the past 100 years, but the landscape remains only partially surveyed. A manuscript normally transmits one text and a melody, and some manuscripts may preserve readings that prove more typical than those in other witnesses. Basing editions on such sources may help readers gain insight into one concrete and tangible trace of the tradition, but editors still need to help them glean alternatives and variants in meaningful ways. If, for example, in the case of Thibaut de Champagne, we make only the melodies of the major chansonniers available to listeners and fail to elucidate the connections among the extant musical interpretations, we shut out the potential for a richer understanding of the trouvère tradition. We silence the micro-variation at discreet moments in the concordant melodies; we miss out on the unica melodies and the rhythmic interpretations that move Thibaut's music a step closer to the conductus and motet; and we overlook the echoes between the trouvère king's songs and the works of Philippe le Chancellier and Adam de la Bassée. It is true that trouvère song was monophonic, but if we attune our ears to melodic variance, it is almost like listening in stereo.

\section{Bibliography}

Alla, Francesca and Brigitte Lesne. 2012. Thibaut de Champagne. Amour courtois et chevalerie au XIII siècle. Paris: Aeon (Outhere-Music-France).

Anglès, Higini. 1973. Las canciones del rey Teobaldo. Pamplona, Excma. Diputación Floral de Navarra.

Appel, Carl. 1934. Die Singweisen Bernarts von Ventadorn, nach den Handschriften mitgeteilt. Halle: Niemeyer.

Aubrey, Elizabeth. 1996. The Music of the Troubadours. Bloomington: Indiana University Press.

Bahat, Avner and Gérard Le Vot. 1996. L'œuvre lyrique de Blondel de Nesle: mélodies. Édition des mélodies et étude des variantes. Paris: Honoré Champion.

Barbieri, Luca. 1999. "Note sul Liederbuch di Thibaut de Champagne". Medioevo Romanzo, 23, pp. 388-416. 
Barnard, Jennifer A. 2008. The Journey of the Soul: The Role of Music in the Ludus super Anticlaudianum of Adam de la Bassée. PhD, University of Bristol.

Baumgartner, Emmanuèle. 1987. "Présentation des chansons de Thibaut de Champagne dans les manuscrits de Paris". In Yvonne Bellenger et Danielle Quéruel (eds), Thibaut de Champagne: Prince et poète au XIII siècle. Lyon: La Manufacture, pp. 35-44.

Bayart, Paul. 1930. Adam de la Bassée (d. 1286): Ludus Super Anticlaudianum d'après le manuscrit original conservé à la Bibliothèque municipale de Lille avec une introduction et des notes. Tourcoing: Georges Frères.

Beck, Jean. 1927. Le chansonnier Cangé. Corpus Cantilenum Mediae Aevi.

Bédier, Joseph and Jean Beck. 1912. Les chansons de Colin Muset. Paris: Honoré Champion.

- - 1938. Les chansons de Colin Muset. $2^{\text {nd }}$ ed. Paris: Honoré Champion.

Calin, William. 1986. “On the Nature of Christian Poetry: From the Courtly to the Sacred and the Functioning of Contrafactum in Gautier de Coinci". In Jaume Vallcorba (ed.), Studia in honorem prof. M. de Riquier. Madrid: Quaderns Crema, pp. 385-94.

Callahan, Christopher and Samuel N. Rosenberg. 2005. Les chansons de Colin Muset. Textes et Mélodies. Paris: Honoré Champion.

. 2012a. "Pour une historique de la notion de genre dans le lyrisme de langue d'oïl: le témoignage des chansonniers". In Marie-Geneviève Grossel (ed.), Registre, genres, formes dans la lyrique des trouvères. Valenciennes: Presses Universitaires de Valenciennes, pp. 43-55.

. 2012b. "Dame polyvalente, glissement registral et contrafacture chez Thibaut de Champagne." Le Moyen Age, 3-4, pp. 581-94.

. 2013. “À la défense des mélodies 'marginales' chez les trouvères: le cas de Thibaut IV de Champagne". Cahiers de Recherches Médiévales et Humanistes, 26(2), pp. 69-90.

Diabolus in Musica, Antoine Guerber. 2005. La douce acordance. Chansons de trouvères. Alpha \& Fondation France Telecom.

Drzewicka, Anna. 1985. "La Fonction des emprunts à la poésie profane dans les chansons mariales de Gautier de Coinci", Le Moyen Age, 91, pp. 33-51, 179-200. 
Duys, Kathryn A. 1997. Books Shaped by Song: Early Literary Literacy in the Miracles de Nostre Dame of Gautier de Coinci. PhD, New York University.

Everist, Mark. 1994. French Motets in the Thirteenth Century: Music, Poetry and Genre. Cambridge: Cambridge University Press.

Formisano, Luciano. 1993. "Prospettive di ricerca sui canzioneri d'autore nella lirica d'oïl". In Saverio Guida and Fortunata Latella (eds), La Filologia romanza e i codici: atti del convegno. Messina: Sicania, pp. 131-52.

Gennrich, Friedrich. 1953-56. Altfranzösische Lieder. Sammlung romanischer Übungstexte, Bd. 36.Tübingen: Halle M. Niemeyer.

- - 1963. Das altfranzösische Rondeau und Virelai im 12. und 13. Jahrhundert. Langen bei Frankfurt: Summa Musicae Medii Aevi, Bd. 10.

Haines, John. 1997. "The 'Modal Theory', Fencing, and the Death of Aubry". Plainsong and Mediaeval Music, 6(2), pp. 143-50.

- 2002 . "The Transformations of the 'Manuscript du roi"', Musica Disciplina, 52, pp. 5-43.

- -2004 . Eight Centuries of Troubadours and Trouvères: The Changing Identity of Mediaeval Music. Cambridge: Cambridge University Press.

Hughes, Andrew. 1970. "The Ludus super Anticlaudianum of Adam de la Bassée". Journal of the American Musicological Society, 23, pp. 1-25.

Karp, Theodore. 1964. "The Trouvère Manuscript Tradition". In Albert Mell (ed.), The Twenty-fifth-Anniversary Festschrift (19371962). New York: Queens College of the City University of New York Department of Music, pp. 25-52.

LePage, Yvan G, ed. 1994. L'CEvre Lyrique de Blondel de Nesle: Textes. Paris: Honoré Champion.

Marshall, John H. 1980. "Pour l'étude des contrafacta dans la poésie des troubadours", Romania, 101, pp. 289-335.

O'Sullivan, Daniel E. 2005. Marian Devotion in Thirteenth-Century French Lyric. Toronto: University of Toronto Press.

-. 2008. "Editing Melodic Variance in Trouvère Song". Textual Cultures, 3(2), pp. 54-70.

-. 2013a. "Stepping Back and Leaping Forward". Textual Cultures, 8(1), pp. 1-5. 
__. 2013b. “On connaît la chanson: la contrafacture des mélodies populaires dans le Ludus anticlaudianum d'Adam de la Bassée". Cahiers de recherches médiévales et humanistes, 26(2), pp. 109-28.

-_. 2015. "Words with Friends, Courtly Edition: Thibaut's de Champagne's Jeux-Partis". In Serina Patterson (ed.), Games and Gaming in Mediaeval Literature. New York: Palgrave MacMillan, pp. 61-78.

- - Forthcoming. "Contrafacture, Lyrical Exchange, and Self-Parody in Thibaut de Champagne's Debate Poetry". Parodies courtoises / Parodies de la courtoisie. Lisbon: Universidade de Lisboa.

Raynaud, Gaston. 1884. Bibliographie des chansonniers français des $\mathrm{XIII}^{e}$ et XIV $\mathrm{V}^{e}$ siècles, comprenant la description de tous les manuscrits, la table des chansons classées par ordre alphabétique de rimes et la liste des trouvères. Paris: F. Vieweg.

Rosenberg, Samuel N. and Hans Tischler. 1981. Chanter m'estuet: Songs of the Trouvères. Bloomington: Indiana University Press.

_- , Samuel Danon and Hendrik van der Werf. 1985. The Lyrics and Melodies of Gace Brulé. New York: Garland.

- - and Hans Tischler, with the collaboration of Marie-Geneviève Grossel. 1995. Chansons des trouvères. Paris: Librairie Générale Française.

-_, Margaret L. Switten and Gérard Le Vot. 1998. Songs of the Troubadours and Trouvères: an Anthology of Poems and Melodies. New York: Garland.

Tischler, Hans. 1997. Trouvère Lyrics with Melodies: Complete Comparative Edition. 15 vols. N.p.: American Institute of Musicology.

Van den Boogaard, Nico. 1969. Rondeaux et refrains : Du XII siècle au début du XIV ${ }^{e}$. Paris: Klincksieck.

Van der Werf, Hendrik. 1972. The Chansons of the Troubadours and Trouvères: A Study of the Melodies and Their Relation to the Poems. Utrecht: A. Oosthoek.

__. 1977-1979. Trouveres-Melodien. Kassel: Bärenreiter. 2 vols.

- - 1984. The Extant Troubadour Melodies: Transcriptions and Essays for Performers and Scholars. Rochester, NY: Published by the author.

Vidal, Raimon. 1972. “Doctrina de Compondre Dictats". In John H. Marshall (ed.), The Razos de Trobar of Raimon Vidal and Associated Texts. London: Oxford University Press, p. 97. 
Wallensköld, Axel. 1925. Les chansons de Thibaut de Champagne, roi de Navarre. Paris: Champion.

Zumthor, Paul. 1972. Essai de poétique médiévale. Paris: Seuil. Trans. Philip Bennet. Minneapolis, University of Minnesota Press. 